\title{
Hypoxic Ischemic Encephalopathy in Units Reporting to the Ibero-American Society of Neonatology Network: Prevalence and Mortality
}

\author{
Fernando Domínguez-Dieppa MD PhD, Marcelo Cardetti MD, Susana Rodríguez MD, Alfredo García-Alix MD, Augusto Sola MD
}

\begin{abstract}
INTRODUCTION Hypoxic ischemic encephalopathy is a neurological condition occurring immediately after birth following a perinatal asphytic episode. Therapeutic hypothermia is a safe and effective intervention to reduce mortality and major disability in survivors. In Latin America, perinatal asphyxia is a major problem, but no data are available characterizing its current situation in the region or the impact of hypoxic ischemic encephalopathy on its management.
\end{abstract}

OBJECTIVE Understand the prevalence, mortality and use of therapeutic hypothermia in newborns at $\geq 36$ weeks gestational age with hypoxic ischemic encephalopathy admitted to neonatal units reporting to the Ibero-American Society of Neonatology Network.

METHODS The Ibero-American Society of Neonatology Network groups various neonatology centers in Latin America that share information and collaborate on research and medical care. We evaluated data on newborns with $\geq 36$ weeks gestational age reported during 2019. Each unit received a guide with definitions and questions based on the Society's 7th Clinical Consensus. Evaluated were encephalopathy frequency and severity, Apgar score, need for resuscitation

\section{INTRODUCTION}

Hypoxic ischemic encephalopathy (HIE) is a neurological syndrome that presents immediately after birth after a perinatal asphytic episode. It is characterized by alterations in alertness, with decreased ability to awaken and maintain muscle tone, decreased motor responses and reactivity. It occurs as a consequence of oxygen deprivation in the brain, from arterial hypoxemia or cerebral ischemia, or both.[1,2]

Therapeutic hypothermia $(\mathrm{TH})$ is the reduction of body temperature by $3-4{ }^{\circ} \mathrm{C}$ in the first 6 hours of life, maintained for 72 hours. It is a safe and effective intervention for reducing mortality and major disability in survivors.[3-5] It is currently the only standard therapy specific to HIE.[1,6-10] The Ibero-American Society of Neonatology (SIBEN) published a guide establishing standards and recommendations for HIE management in Latin America aimed at promoting a comprehensive therapeutic approach, including recommendation of $\mathrm{TH}$.[1]

\section{IMPORTANCE}

This study, the first of its kind, provides data from healthcare institutions in Latin America related to hypoxic ischemic encephalopathy in neonates and can be used as a basis for determining mortality and improving access to therapeutic hypothermia in the region. at birth, use of therapeutic hypothermia and clinical evolution at discharge. Our analysis includes descriptive statistics and comparisons made using the chi-square test.

RESULTS We examined reports of 2876 newborns from 33 units and 6 countries. In 2849 newborns with available data, hypoxic encephalopathy prevalence was 5.1\% (146 newborns): 27 (19\%) mild, 36 $(25 \%)$ moderate, $43(29 \%)$ severe, and $40(27 \%)$ of unknown intensity. In those with moderate and severe encephalopathy, frequencies of Apgar scores $\leq 3$ at the first minute $(p=0.001)$, Apgar scores $\leq 3$ at the fifth minute $(p<0.001)$ and advanced resuscitation $(p=0.007)$ were higher. Therapeutic hypothermia was performed in only $13 \%$ of newborns (19). Neonatal mortality from encephalopathy was $42 \%$ (61).

CONCLUSION Hypoxic ischemic encephalopathy is a neonatal condition that results in high mortality and severe neurological sequelae. In this study, the overall prevalence was $5.1 \%$ with a mortality rate of $42 \%$. Although encephalopathy was moderate or severe in $54 \%$ of reported cases, treatment with hypothermia was not performed in $87 \%$ of newborns. These data reflect a regional situation that requires urgent action.

KEYWORDS Hypoxia ischemia, brain; encephalopathy, neonatal; mortality; hypothermia, induced; neonatology; Latin America

According to $\mathrm{WHO}$, in 2017 some 2.5 million children died in their first month of life. This is approximately 7000 newborns each day, 1 million in the first day of life and nearly 1 million in the following 6 days.[11] Globally, the leading direct causes of neonatal death are preterm birth $(28 \%)$, severe infections $(26 \%)$ and asphyxia $(23 \%)$. [12] These three causes account for three quarters of neonatal mortality worldwide.[13]

HIE is one of the leading causes of neonatal death and permanent disability, and its contribution to the health burden is high, in terms of years of life lost and years lived with disability. In addition to the important contribution of asphyxia to perinatal mortality, it is estimated that more than one million newborns who survive it annually develop cerebral palsy, epilepsy, learning disabilities and other developmental problems.[6-8] The risk of major disability in those who survive is high. Without $\mathrm{TH}$, the risk of death or major disability with moderate HIE is $52 \%$ and with severe HIE approximately $78 \%$.[10]

In the 20th century, no specific therapeutic interventions were performed to prevent or ameliorate brain damage associated with HIE perinatal aggression. Neonates with moderate and severe HIE constitute a therapeutic challenge due to the associated risk of death or neurological sequelae. The medical, social and legal implications associated with this devastating condition are of consequence and represent an important social and health problem.[14] In Latin America, composed of low- and middleincome countries, perinatal asphyxia is a major problem, and 
it can be assumed that thousands of newborns do not receive adequate care. While precise information is available regarding the extent of this problem and its impact in Europe, Canada and the United States, reliable information is not available for Latin American countries; with the exception of Cuba, where there are recent reports.[15]

The scarce published data for Latin America describe singlecenter experiences in large cities, with small patient numbers.[1] These data estimate HIE incidence at $4 \%-6.2 \%$ of live newborns and risk of death at $10 \%-20 \%$ in neonates with moderate HIE, and $>60 \%$ in those with severe HIE.[1] However, these data almost assuredly underestimate the reality of the current situation.

The SIBEN Network brings together various Latin American neonatology units for information sharing and collaboration in research and patient care. The units maintain their autonomy while participating in a joint effort aimed at a common objective: promote continuous improvements in the quality of care offered by each. The Network thus facilitates comparative evaluation among participating units and centers, collaborating to implement good clinical practices that may influence care throughout the region. Network participation is free for SIBEN members. Currently, 45 neonatal intensive care units (NICUs) in 9 Latin American countries belong.

It is essential and urgent to improve the quality and accessibility of information on HIE's magnitude in Latin America in order to: 1) characterize perinatal care in the region; 2) obtain objective data that allow for monitoring changes over time; 3) understand healthcare needs generally and for specific geographic areas, to develop plans for improvement and to correct inequalities in the care of newborns with perinatal asphyxia-HIE; and 4) systematize and rationalize efforts aimed at improving care for asphytic neonates who develop HIE.

The objective of this study was to determine the prevalence of $\mathrm{HIE}$ in neonates at $\geq 36$ weeks of gestational age (GA) admitted to NICUs that participated in the SIBEN Network registry in 2019 , and to understand related mortality rates and the use of therapeutic hypothermia.

\section{METHODS}

The 45 units comprising the SIBEN Network are in the public sector. All were invited to participate in this study. However, since only 33 units in 6 countries (Argentina, Brazil, Ecuador, Peru, the Dominican Republic and Venezuela) report data on newborns at $\geq 36$ weeks GA, we used data exclusively from these units. There were great disparities in numbers of centers reporting (and thus the numbers of newborns included per country): 18 from Argentina, 11 from the Dominican Republic, and 1 each from Ecuador, Peru, Brazil and Venezuela. Newborns with major congenital malformations were excluded from our research. The study population thus included 2876 newborns (at $\geq 36$ weeks GA) admitted to 33 neonatal intensive care units from January 1, 2019 through December 31, 2019.

A clinical care guide was distributed to each of the participating units, accompanied by a list of requested data, both based on the therapeutic recommendations from the 7th SIBEN Clinical Consensus for Neonatal HIE.[1] Accordingly, HIE severity was classified in three grades: mild, moderate and severe. In addition to neurological dysfunction after delivery, HIE diagnosis was established when the newborn had a history of potential hypoxic ischemic aggression during delivery (e.g., a sentinel event or alteration of the fetal cardio-topographic record) and/or alteration of status at birth (Apgar $<5$ at 10 minutes, $\mathrm{pH}$ in the first hour $\leq 7.0$, or the need for advanced cardiopulmonary resuscitation).[1]

\section{Study variables We collected the following:}

- Apgar score at 1 minute and 5 minutes

- HIE severity by grade

- use of advanced cardiopulmonary resuscitation (CPR) when the newborn required endotracheal intubation

- fraction of inspired oxygen $\left(\mathrm{FiO}_{2}\right)$ during resuscitation

- presence of seizures

- use of TH (body or brain)

- mortality during hospitalization (death of the newborn before discharge and death of the newborn attributable to HIE)

We analyzed the data using descriptive statistics, summary measures, frequency tables and graphs.

This study complies with the internationally accepted ethical recommendations established by the Declaration of Helsinki, in its current version.[16]

\section{RESULTS}

2876 newborns admitted to neonatal intensive care units in 33 healthcare institutions in 6 countries were reported to the SIBEN Network from January 1, 2019 through December 31, 2019 (Table 1). Due to the large differences in the number of reports by geographic location, the newborns were analyzed as a group, without making comparisons among NICUs or countries.

Frequency and severity of HIE reported to the SIBEN Network Data was not reported on HIE for 27 of the 2876 newborns. Among the remaining 2849 newborns with available data, 146 cases of HIE (5.1\%) were reported, classified according to severity (Table 2 ). Severity was not reported for 40 $(27.4 \%)$, and thus these are not included in Table 2, although they are added for the total count. The absolute frequencies and percentages corresponding to the Apgar categories at one minute and five minutes, clinical seizures, advanced resuscitation, $\mathrm{TH}$ use and mortality are also reported.

Apgar score Out of the cohort of 2876 newborns, 275 (9.6\%) with an Apgar score $\leq 3$ in the first minute of life and $258(8.6 \%)$

Table 1: Case data supplied to SIBEN Network

\begin{tabular}{|l|r|r|}
\hline Country & $\begin{array}{c}\text { Number of NICUs } \\
\text { reporting }\end{array}$ & $\begin{array}{c}\text { Number of newborns } \\
\text { reported }\end{array}$ \\
\hline Dominican Republic & 11 & 1839 \\
\hline Argentina & 18 & 1002 \\
\hline Ecuador & 1 & 14 \\
Peru & 1 & 10 \\
\hline Brazil & 1 & 7 \\
Venezuela & 1 & 4 \\
\hline Total & 33 & 2876
\end{tabular}

NICU: neonatal intensive care unit 
Table 2: Apgar score, advanced resuscitation, seizures, therapeutic hypothermia use, and mortality by HIE severity

\begin{tabular}{|c|c|c|c|c|c|c|c|c|}
\hline & \multicolumn{6}{|c|}{ HIE } & \multirow{2}{*}{\multicolumn{2}{|c|}{$\begin{array}{c}\text { Total }^{*} \\
(\mathrm{~N}=146)\end{array}$}} \\
\hline & \multicolumn{2}{|c|}{$\begin{array}{c}\text { Mild } \\
(\mathrm{N}=27) \\
\end{array}$} & \multicolumn{2}{|c|}{$\begin{array}{c}\text { Moderate } \\
(\mathrm{N}=36)\end{array}$} & \multicolumn{2}{|c|}{$\begin{array}{c}\text { Severe } \\
(\mathrm{N}=43)\end{array}$} & & \\
\hline & $\mathbf{n}$ & $\%$ & $\mathbf{n}$ & $\%$ & $\mathbf{n}$ & $\%$ & $\mathrm{n}$ & $\%$ \\
\hline \multicolumn{9}{|c|}{ Apgar score (minutes) } \\
\hline$\leq 3$ & 15 & 55.6 & 33 & 91.7 & 35 & 81.4 & 111 & 76.0 \\
\hline$>3$ & 12 & 44.4 & 3 & 8.3 & 8 & 18.6 & 35 & 24.0 \\
\hline \multicolumn{9}{|c|}{ Apgar score (minutes) } \\
\hline$\leq 5$ & 11 & 40.7 & 33 & 91.7 & 33 & 76.7 & 103 & 70.5 \\
\hline$>5$ & 16 & 59.3 & 3 & 8.3 & 10 & 23.3 & 43 & 29.5 \\
\hline \multicolumn{9}{|c|}{ Advanced resuscitation } \\
\hline Yes & 8 & 29.6 & 20 & 55.6 & 27 & 62.8 & 74 & 50.7 \\
\hline No & 19 & 70.4 & 16 & 44.4 & 16 & 37.2 & 72 & 49.3 \\
\hline \multicolumn{9}{|l|}{ Selzures } \\
\hline Yes & 10 & 37.0 & 29 & 80.6 & 30 & 69.8 & 98 & 67.1 \\
\hline No & 17 & 63.0 & 7 & 19.4 & 13 & 30.2 & 48 & 32.9 \\
\hline TI use & 2 & 7.4 & 4 & 11.1 & 8 & 18.6 & 19 & 13.0 \\
\hline Mortality & 3 & 11.1 & 14 & 38.9 & 26 & 60.5 & 61 & 41.8 \\
\hline
\end{tabular}

* Includes cases in which HIE severity was not reported during hospitalization.

$\mathrm{n}$ : number of cases \%: percentage with respect to total cases

HIE: hypoxic ischemic encephalopathy $\mathrm{TH}$ : therapeutic hypothermia

with a score $\leq 5$ at 5 minutes were reported. Of the 146 newborns who presented with HIE, $111(76 \%)$ had an Apgar score of $\leq 3$ at 1 minute of life and $103(70.5 \%) \leq 5$ at 5 minutes of life. Low Apgar scores were much more common in the moderate and severe forms of HIE (Table 2).

Seizures Of the 146 newborns with HIE, 98 (67.1\%) experienced seizures. Seizures were also much more common in moderate and severe forms of HIE (Table 2).

Resuscitation according to HIE severity Advanced resuscitation was necessary in 74 newborns with HIE (51\%) (Table 2). The likelihood of advanced resuscitation obviously increased with HIE severity. Of the 20 newborns with moderate HIE who received advanced CPR, 9 (45\%) required cardiac massage and $4(20 \%)$ required vasoactive medication. Of the neonates with severe HIE, $27(63 \%)$ required advanced CPR, of which $22(81 \%)$ required cardiac massage and $11(41 \%)$ required medication. Only $11 \%$ of newborns were resuscitated with $21 \% \mathrm{FiO}_{2}$ and $40 \%$ were resuscitated with $100 \%$ oxygen. $\mathrm{FiO}_{2}$ data was not reported for the remaining $49 \%$.

Therapeutic hypothermia Only 19 of the 146 newborns with HIE $(13 \%)$ were treated with TH (mild HIE: 2, moderate HIE: 4, severe HIE: 8, with unknown severity: 5) (Table 2). Of those treated with $\mathrm{TH}, 75 \%$ received body cooling and $25 \%$ received selective brain cooling. It is obvious that, regardless of the severity of HIE, TH use is infrequent.

Mortality Among the 2876 newborns, mortality reported was $11 \%$ (310 newborns) while mortality in the 146 newborns with HIE was $42 \%(61 / 146)$, which is positively correlated with HIE severity. Of the 61 newborns with HIE who died, 37 cases $(60.7 \%)$ were directly attributable to $\mathrm{HIE}$, regardless of severity. In the remaining $24(39.3 \%)$, death was attributed to sepsis, meningitis, respiratory failure, hypoxemia, kernicterus and other causes.

\section{DISCUSSION}

HIE is a neonatal condition that results in high mortality and severe neurological sequelae.[1-3] In this study, HIE prevalence in newborns at $\geq 36$ weeks GA admitted to SIBEN Network centers was $5.1 \%$ with a mortality rate of $42 \%$, almost four times that of non-HIE newborns at the same GA reported to the Network. Although HIE severity was not reported for all newborns, in $54 \%$ of reported cases it was either moderate or severe. These data do not represent all of Latin America nor the reality of each country, as our sample corresponds to voluntary reporting made by only some of the neonatal units within the region. However, even with the aforementioned limitations of our sample, these data reflect a situation demanding urgent action.

TH has proven benefits for newborns with HIE,[10,15,17-23], among which the reduction in mortality or neurodevelopmental alterations at 18 months stands out with a relative risk (RR) of $0.75,95 \% \mathrm{Cl}(0.68-0.83)$.[17] $\mathrm{TH}$ has few side effects and its implementation is relatively simple. However, TH was only used in a small number of newborns with HIE in this sample, and it remains unavailable in many centers throughout the region. In the SIBEN Network during the study period, $87 \%$ of neonates who presented with $\mathrm{HIE}$ did not receive $\mathrm{TH}$, and of the 79 reported with moderate or severe HIE, only $12(15 \%)$ had access to $\mathrm{TH}$. It is highly probable that the mortality rate in these newborns would have been lower if $\mathrm{TH}$ had been available and applied. Even though we do not know the neurological evolution of these newborns after discharge, evidence shows that $\mathrm{TH}$ leads to reduced rates of major disability associated with HIE and therefore better long-term neurological outcomes.[17]

As is the case with other health indicators, no Latin American countries present national data on prevalence and clinical evolution of newborns with HIE, with the exception of Cuba, where HIE frequency in 2017 and 2018 was comparable to rates in high-income countries. HIE mortality rates in Cuba of $12 \%$ and $17 \%$ (for 2017 and 2018, respectively) cannot be stratified by HIE severity since, as of this writing, the Cuban national registry has not yet recorded this data for later analysis. Unlike Latin America, other regions have working groups that track information related to HIE incidence, its severity, conditions available for comprehensive care and the TH implementation. [24,25] In a cross-sectional study conducted in 57 Spanish hospitals, $95 \%$ of those surveyed used servo-controlled total body cooling and had established protocols specific to HIE patient care.[26]

This study does not include an analysis of the use of oxygen in advanced resuscitation procedures. The universal recommendation is to use ambient air $\left(21 \% \mathrm{FiO}_{2}\right)$. However, this was the case in only $11 \%$ of newborns resuscitated in this sample. Some $40 \%$ were resuscitated with $100 \%$ oxygen, despite ample evidence advising against this practice and the damage the hypoxia-reperfusion-hyperoxia cycle can have on the brain. [27-31]

Any process aimed at improving quality of care for newborns with HIE must be based on reliable information. This is the first study involving Latin American countries that provides data on this important problem. Comprehensive care of newborns affected by HIE is multi-faceted and must include the 
availability of adequate resuscitation with trained personnel in the delivery room, avoiding inappropriate use of oxygen; rapid clinical diagnoses; the ability to assess HIE severity, and use of previously validated care protocols. Timely care for families is essential, as is $\mathrm{TH}$ provision in the NICU or potential for patient referral to a center capable of providing $\mathrm{TH}$ within the first six hours of life. Finally, given the consequences HIE has for neurodevelopment and quality of life for both children and their families, specialized followup programs should be established to identify and treat neurodevelopmental issues in a timely manner, and offer support and guidance to families.[32]

\section{CONCLUSIONS}

Hypoxic ischemic encephalopathy is a neonatal condition responsible for high mortality rates and severe neurological sequelae. HIE prevalence in this study was $5.1 \%$, with an overall mortality rate of $42 \%$. Despite the fact that HIE was graded as either moderate or severe in $54 \%$ of cases, therapeutic hypothermia was not performed on $87 \%$ of neonates presenting with HIE. This is the first study published containing multicenter data on HIE in Latin America, and it demonstrates an urgent need for the implementation of programs to improve the quality of care available for newborns with neonatal encephalopathy. - 1 .

\section{REFERENCES}

1. Lemus Varela ML, Sola A, Golombek SG, Baquero H, Dávila CR, Fariña D, et al. Recomendaciones terapéuticas del VII Consenso Clínico de SIBEN para la encefalopatía hipóxico-isquémica neonatal. NeoReviews. 2016;17(9):e554-67. Spanish.

2. García Alix A, Martínez-Biarge M, Arnaez J, Valverde E, Quero J. Asfixia Intraparto y encefalopatía hipóxico isquémica. In: Protocolos Diagnóstico Terapéuticos [Internet]. Madrid: Asociación Española de Pediatría AEP: Neonatología; 2008 [cited 2020 Mar 27]. 11 p. Available at: https://www.aeped.es/sites/default/files/docu mentos/26.pdf. Spanish.

3. García Alix A, Martínez-Biarge M, Diez J, Gayá F, Quero J. Incidencia y prevalencia de la encefalopatía hipóxico-isquémica en la primera década del siglo XXI. An Pediatr (Barc). 2009 Oct;71(4):319-26. Spanish.

4. Ruiz Peláez JG, Romero-Pradilla R, BuitragoLópez A. Guía práctica clínica del recién nacido con asfixia perinatal [Internet]. Bogotá: Ministry of Health and Social Protection of Colombia; 2013 Apr [cited 2020 Mar 27]. p. 1-38. Available at: https://www.minsalud.gov.co/sites/rid/Lists/Bi bliotecaDigital/RIDE/INEC/IETS/GPC_Completa Asfix.pdf. Spanish

5. Novoa J, Milad M, Fabres J, Fasce J, Toso $\mathrm{P}$, Arriaga $\mathrm{M}$, et al. Consenso sobre el manejo integral del neonato con encefalopatía hipóxico isquémica. Rev Chilena Pediatría. 2012;83(5):492-501. Spanish.

6. Rizzotti A, Bas J, Cuestas E. Meta análisis sobre la eficacia y seguridad de la hipotermia en el tratamiento de la encefalopatía hipóxico isquémica. Rev Facultad Cienc Méd. 2010;67(1):15-23. Spanish.

7. Medina Alva MP, Rivera Abbiati F, Tri Murgueytio AA, Montiel Blanco J, Guillén Pinto RD. Frecuencia, características y mortalidad asociada a la enfermedad neurológica en la unidad de cuidados intensivos neonatales del Hospital Cayetano Heredia. Rev Perú Pediatr. 2007 JanApr;60(1):11-9. Spanish.

8. Booth D, Evans DJ. Anticonvulsants for neonates with seizures. Cochrane Database Syst Rev. 2004 Oct 18;4:CD004218.

9. Thompson CM, Puterman AS, Linley LL, Hann FM, van der Elst CW, Molteno CD, et al. The value of a scoring system for hypoxic ischaemic encephalopathy in predicting neurodevelopmental outcome. Acta Paediatr. 1997:86(7):757-61.

10. Tagin MA, Woolcott CG, Vincer MJ, Whyte RK, Stinson DA. Hypothermia for neonatal hypoxic ischemic encephalopathy: an updated systematic review and meta-analysis. Arch Pediatr Adolesc Med. 2012 Jun 1;166(6):558-66.

11. World Health Organization [Internet]. Geneva: World Health Organization; c2020. Centro de prensa. Reducir la mortalidad de los recién nacidos; 2019 Dec 19 [cited 2020 Aug 1]; [about 4 p.].
Available at: https://www.who.int/es/news-room/ fact-sheets/detail/newboRN-reducing-mortality. Spanish.

12. Lawn JE, Cousens S, Zupan J; Lancet Neonatal Survival Steering Team. 4 million neonatal deaths: when? Where? Why? Lancet. 2005 Mar 5-11;365(9462):891-900.

13. Disminuye la mortalidad neonatal, pero aumenta su proporción en la mortalidad en la niñez a escala mundial. Geneva: World Health Organization; 2011 [cited 2020 Aug 8]. Available at: https:// www.who.int/mediacentre/news/releases/2011/ newborn deaths 20110830/es/\#:. Spanish.

14. Grupo de Trabajo Hipotermia Terapéutica, Comité de Estudios Feto-Neonatales (CEFEN). Recomendación para el tratamiento con hipotermia en recién nacidos con encefalopatía hipóxicoisquémica. Arch Argent Pediatr. 2017;115 Suppl 3:S38-52. Spanish.

15. Franco AO, Coca ÁG, Domínguez DF, Andrés $A D$, Andino $A D$. La encefalopatía hipóxico isquémica en una unidad de cuidados intensivos. Rev Cubana Pediatr. 2017;89(4). Spanish.

16. WMA Declaration of Helsinki - Ethical Principles for Medical Research Involving Human Subjects 64th WMA General Assembly, Fortaleza, Brazil, October 2013 [Internet]. Ferney-Voltaire (FR): World Medical Association; 2013 Oct [cited 2020 Aug 8]. Available at: https://www.wma .net/policies-post/wma-declaration-of-helsinki -ethical-principles-for-medical-research-involving -human-subjects/

17. Shah PS. Hypothermia: a systematic review and meta-analysis of clinical trials. Semin Fetal Neonatal Med. 2010;15(5):238-46.

18. Jacobs SE, Berg $M$, Hunt $R$, Tarnow-Mordi WO, Inder TE, Davis PG. Cooling for newborns with hypoxic ischaemic encephalopathy. Cochrane Database of Syst Rev. 2013 Jan 31;2013(1):CD003311.

19. Saliba E, Debillon T. [Hypothermia for hypoxicischemic encephalopathy in full term newborns]. Arch Pediatr. 2010 Sep;17 Suppl 3:S67-77. French.

20. National Institute for Health and Care Excellence. NICE interventional procedure guidance [IPG347]: Therapeutic hypothermia with intracorporeal temperature monitoring for hypoxic perinatal brain injury [Internet]. [cited 2016 Jun 16]. Available at: http://www.nice.org.uk/guidance/ ipg347.

21. Blanco D, García-Alix A, Valverde E, Tenorio V, Vento M, Cabañas F; Comisión de Estándares de la Sociedad Española de Neonatología. [Neuroprotection with hypothermia in the newborn with hypoxic-ischaemic encephalopathy. Standard guidelines for its clinical application]. An Pediatr (Barc). 2011 Nov;75(5):341.e1-20. Spanish.

22. Peliowski-Davidovich A; Canadian Paediatric Society, Fetus and Newborn Committee. Hypothermia for newborns with hypoxic ischemic encephalopathy. Paediatr Child Health. 2012 Jan;17(1):41-6. English, French.

23. Takenouchi $\mathrm{T}$, Iwata $\mathrm{O}$, Nabetani M, Tamura M. Therapeutic hypothermia for neonatal encephalopathy: JSPNM \& MHLW Japan Working Group Practice Guidelines Consensus Statement from the Working Group on Therapeutic Hypothermia for Neonatal Encephalopathy, Ministry of Health, Labor and Welfare (MHLW), Japan, and Japan Society for Perinatal and Neonatal Medicine (JSPNM). Brain Dev. 2012 Feb;34(2):165-70.

24. Guía de Práctica Clínica sobre Encefalopatía Hipóxico-Isquémica Perinatal en el recién nacido. Catalunya: Ministerio de Sanidad, Servicios Sociales e Igualdad Agencia de Qualitat i Avaluacio Sanitaries de Catalunya (AQuAS); 2015. 271 p. Spanish.

25. Arnaez J, García Alix A, Arca G, Valverde E, Caserío S, Moral TM, et al. Incidencia de la encefalopatía hipóxico-isquémica e implementación de la hipotermia terapéutica por regiones en España. An Pediatr (Barc). 2018 Jul;89(1):1223. Spanish.

26. Arnaez J, Herranz Rubia N, García Alix A; Grupo de Trabajo EHI-ESP. Atención integral del neonato con encefalopatía hipóxico-isquémica en España. An Pediatr (Barc) [Internet]. 2020 May 1;92(5):286-96. Available at: https://doi .org/10.1016/j.anpedi.2019.05.013. Spanish.

27. Sola A, Rogido MR, Deulofeut R. Oxygen as a neonatal health hazard: call for détente in clinical practice. Acta Paediatr. 2007 Jun;96(6):801-12.

28. Sola A. Oxygen saturation in the newborn and the importance of avoiding hyperoxia-induced damage. Neo Reviews. 2015 Jul;16(7):e393-405.

29. Rabi Y, Rabi D, Yee W. Room air resuscitation of the depressed newborn: a systematic review and meta-analysis. Resuscitation. 2007 Mar:72(3):353-63.

30. Perlman JM, Wyllie J, Kattwinkel J, Wyckoff $\mathrm{MH}$, Aziz K, Guinsburg R, et al. Part 7: Neonatal resuscitation: 2015 international consensus on cardiopulmonary resuscitation and emergency cardiovascular care science with treatment recommendations. Circulation. 2015 Oct 20;132(16 Suppl 1):S204-41.

31. Soll RF. The use of oxygen in the delivery room. Pediatrics. 2019 Jan;143(1):e20183365. DOI: https://doi.org/10.1542/peds.2018-3365

32. Martínez-Biarge M, Blanco D, García-Alix A, Salas S; Grupo de Trabajo de Hipotermia de la Sociedad Española de Neonatología. Seguimiento de los recién nacidos con encefalopatía hipóxico-isquémica. An Pediatr (Barc). 2014 Jul;81(1):52.e1-14. DOI: 10.1016/j.anpedi.2013 .06.015. Spanish.

\section{ACKNOWLEDGMENTS}

We are grateful to the following specialists for collecting and reporting data to the SIBEN Net- 


\section{Original Research}

work: Maria Rosa Frias, Diego Depietro, Ignacio Sosa, Belen Falco, Maiara Celiz, Segundo Jaime Sánchez, Anabell Pereira, María Elisa Villoldo, Carolina Pinto, Cristiane Ribeiro, María Rosa Gonzalez, Amantina Peña, Sujey Vargas, Candelaria Nuñez, Maria Victoria Vulcano, Arielina Felix, Maritza Ramos Medina, Nadia Rosario, Taína Malena, Mónica Menzio, Veronica Favareto, Ana Medina, Odris Tejera and Joselyn Acosta.

\section{THE AUTHORS}

Fernando Domínguez-Dieppa (Corresponding author: fddieppa@infomed.sld.edu), neonatologist with a PhD in medical sciences. Member of the board of directors and ethics department, Ibero-American Neonatology Society (SIBEN) Network. Full (consulting) professor of pediatrics and neonatology, Medical University of Havana, Cuba. https://orcid .org/0000-0003-3971-5612

Marcelo Cardetti, physician. Board member and chief of the Clinical Neonatology and Maternity Services at the Endocrinology and Human Reproduction Center, San Luis, Argentina. https://orcid.org/0000-0001-6697-6389

Susana Rodríguez, physician. Board member, SIBEN Network, director of teaching and research, Juan P. Garrahan Hospital, Buenos Aires, Argentina. https://orcid.org/0000-0001 $-6015-6048$
Alfredo García-Alix, physician. Sant Joan de Deu Pediatric Research Institute, Nene Foundation, University of Barcelona, Barcelona, Spain. https://orcid.org/0000-0002-7972-8453

Augusto Sola, neonatologist. Medical director of the SIBEN Network, California, USA. https:// orcid.org/0000-0002-7608-3872

Submitted: June 9, 2020

Approved for publication: December 29, 2020 Disclosures: None 